\title{
Effects of Acorus calamus Rhizome Extract on the Neuromodulatory System in Restraint Stress Male Rats
}

\section{Kusıtlama Stresli Erkek Suçanlarda Nöromodülatuar Sistem Üzerinde Acorus calamus Rizom Ekstresinin Etkileri}

Sudarshan REDDY', Gayathri RAO ${ }^{1}$, Beena SHETTY ${ }^{1}$, Gopalakrishna $\mathrm{HN}^{2}$

${ }^{1}$ Kasturba Medical College, Department of Biochemistry, Mangalore, Manipal University, India, India

${ }^{2}$ A J Institute Medical Sciences, Department of Pharmacology, Mangalore, India

Corresponding Author: Gayathri M RAO / E-mail: gayathri.rao@manipal.edu

\begin{abstract}
AIM: Prolonged exposure to stress mainly affects the cognitive functions of the brain by inducing neuronal damage mediated through oxidative stress. Acorus calamus (AC) has long been used in Indian folk medicine for various central nervous system (CNS) abnormalities. Hence the present study investigates the effect $A C$ on learning and memory in rats.

MATERIAL and METHODS: Adult Wistar male rats were subjected to restrained stress for 21 days (6hr/day) and the animals were concurrently administered AC for 21 days orally. The Hebb-Williams maze and elevated plus maze served as standard behavioural models for testing memory. The rats were sacrificed on 22nd day and the brain homogenate was taken for various biochemical assessments.

RESULTS: Sodium potassium ATPase activity and TBARS levels showed a significant decrease in the stress group compared to control. After administration of AC, the activity of Na- K- ATPase and levels of TBARS showed a tendency to revert back to normal. However there was no effect on AOPP levels, even after the treatment, which remained high.

CONCLUSION: The present study shows the preventive action of AC rhizome powder on stress induced cognitive functions and modulatory effect on antioxidants and Na-K-ATPase activity.
\end{abstract}

KEYWORDS: Restraint stress, Acorus calamus, Elevated plus maze, Hebb-Williams maze, Rat, TBARS

öz

AMAÇ: Strese uzun süreli maruz kalma oksidatif stres yoluyla oluşan nöronal hasarı indükleyerek, temel olarak beynin kognitif işlevlerini etkiler Acorus calamus (AC) uzun süredir Hint halk tıbbında çeşitli merkezi sinir sistemi (MSS) anormallikleri için kullanılmıştır. Bu nedenle mevcut çalışma AC'nin sıçanlarda öğrenme ve bellek üzerine etkilerini incelemektedir.

YÖNTEM ve GEREÇLER: Yetişkin Wistar erkek sıçanlar 21 gün (6/gün) boyunca kısıtlama stresine maruz bırakılmış ve hayvanlara sonra 21 gün boyunca oral yoldan AC verilmiştir. Hafıza testi için standart davranışsal modeller olarak Hebb-Williams labirenti ve yükseltilmiş artı labirenti kullanılmıştır. Sıçanlar 22. günde sakrifiye edilmiş ve çeşitli biyokimyasal değerlendirmeler için beyin homojenatı alınmıştır.

BULGULAR: Sodyum potasyum ATPaz aktivitesi ve TBARS düzeyleri stres grubunda kontrole göre önemli ölçüde azalmıştır. AC uygulanması ile Na-K-ATPaz aktivitesi ve TBARS düzeyleri normale dönme eğilimi göstermiştir. Ancak tedaviden sonra bile AOPP düzeyleri yüksek kalmış ve bir etki görülmemiştir.

SONUÇ: Mevcut çalışma AC rizom tozunun stres tarafından indüklenen kognitif işlevler üzerinde koruyucu etkisini ve antioksidanlarla Na-KATPaz aktivitesi üzerinde modülatuar etkisini göstermektedir.

ANAHTAR SÖZCÜKLER: Kısıtlama stresi, Acorus calamus, Yükseltilmiş plus labirent, Hebb-Williams labirenti, Sıçan, TBARS

\section{INTRODUCTION}

Stress is a psychological or emotionally disturbing condition that results from the body's response to the adverse external stimuli by bringing up alteration in cellular homeostasis. The exact mechanism(s) involved in the stress-induced brain damage is still debatable. The major phenomenon related to stress response is the activation of hypothalamo-hypophysealadrenal (HPA) axis with an increased brain corticosterone level that in turn affects expression of neurotransmitters and synaptic proteins. Stress may alter variety of central nervous system mediated processes including locomotor activity, sleep, mood, feeding behavior, sexual activity, neuroendocrine and cognitive function (22). All the abovementioned stress-induced behavioral changes are attributed to the involvement of neurotransmitters, synaptic proteins and neurotropic factors in hippocampus and neocortex. 
Modern psychotropic drugs used for the treatment of mental illnesses have side effects ranging from sedation and hypotension to extra-pyramidal symptoms. Various medicinal plants were known to be useful in the treatment of stresslinked mental health complications (25). One such medicinal plant is Acorus calamus (AC).

Acorus calamus (AC) Linn, also called as sweet flag is a native plant of India. It belongs to the araceae family. AC has been used in the Chinese and Indian system of medicine for hundreds of years to cure major CNS anomalies $(10,14,19)$. In ayurvedic medicine, it is used either as component ayurvedic preparations or alone for the management of melancholia, insomnia, hysteria, epilepsy, dementia, and neurosis (19). Root and rhizome extracts of AC Linn. have CNS depressing, tranquilizing and inhibitory action on spontaneous motor activity (15).

Hence, the present study was aimed to explore the neuroprotective effects of $A C$ on adult male rats exposed to chronic restraint stress induced memory impairment and also possible imbalance of oxidant and antioxidant system.

\section{MATERIAL and METHODS}

\section{Animals}

In present study, we employed adult male albino rats (140$170 \mathrm{~g}$ ) procured from central animal House, Kasturba Medical College, Mangalore, India. In house bred male Wistar rats and maintained under environmentally controlled conditions of light, temperature and humidity were the subjects of the study. Animals were free access to rodent chow and tap water. The animal studies were carried out upon institutional animal ethical committee approval. Each study group was consists of six animals. Testing was carried out in suitable environmental conditions between 9-14 h.

\section{Drugs and Chemicals}

Acorus calamus rhizome extract was purchased from natural remedies, Bangalore. Reagents and Chemicals required for the study are HPLC or analytical grade (Sigma, St. Louis, Mo, U.S.A.) obtained from Sri Durga Laboratories, Mangalore, Karnataka, India

\section{Experimental Design}

All the animals in this study were randomly divided into four groups and six animals in each group.

Group 1: Normal control.

Group 2: Rats were exposed to restraint stress $6 \mathrm{~h}$ per day for 21days.

Group 3: received both restraint stress and Acorus calamus (100 mg/kg /day, orally) for 21 days.

Group 4: received both restraint stress and Acorus calamus (200 mg/kg /day, orally) for 21 days.

\section{Experimental Procedure}

\section{Stressing procedure}

Rats were exposed to stress by placing them in a closed wire mesh restrainer with a thick wooden base and stainless steel wire mesh hinged to the base. The dimensions are $11 \mathrm{~cm} \mathrm{(L)}$ $\times 8 \mathrm{~cm}(\mathrm{~B}) \times 8 \mathrm{~cm}(\mathrm{H})$ It is equipped with a pad lock to secure the rats in a static position without any uneasiness, pain and suffocation. (20)

\section{Behavioral Assessment}

\section{Elevated plus maze}

Elevated plus-maze is used to assess anxiety-like behaviour in rats. This test was performed on 22nd day single trial per animal (15). The elevated maze (Techno, India) resembles a cross-shaped maze with two open arms (16 X5 in cm) and two covered arms $(16 \times 5 \times 12 \mathrm{~cm})$, which is elevated above $(25$ $\mathrm{cm}$ ) from the floor. Individual rats were sited on to the central dais and kept in observation for $5 \mathrm{~min}$. The behavioural performance was noted, when anxious, rodents tend to prefer the closed arm. Anxiety-related behaviour is directly related to the degree of avoidance of the open arm entry.

\section{Hebb-Williams maze}

H.W maze test was performed on 22nd day (8). The length of time it takes an animal to navigate a maze to which it has been previously exposed can be used as a test of spatial learning and memory. The faster the animal navigates the maze, the better its spatial memory and decrease in time the animal takes in reaching reward/food chamber on following maze exposures was taken as an account of successful retention. Hebb-Williams maze is slightly larger, approximately $75 \mathrm{~cm}$ x $75 \mathrm{~cm}$ with $25 \mathrm{~cm}$ walls. A proportionally-sized start and a goal box are located at opposite corners of the maze, and the goal box contains a small recessed food cup for reward administration.

\section{Oxidant/antioxidant Systems Measurement in Brain}

Tissue processing: Biochemical parameters were checked 24 hours after the behavioural test (on the $22^{\text {nd }}$ day). Six male rats were sacrificed by decapitulization, always between 8.00 - 10.00 AM to prevent any possible rhythmic alteration in the antioxidant enzyme levels.

The brain was removed and rinsed with $0.1 \mathrm{M}$ phosphate buffer saline ( $\mathrm{pH}$ 7.4). Tissue was weighed and homogenized $(1: 10 \mathrm{w} / \mathrm{v})$ in $0.1 \mathrm{M}$ phosphate buffer saline. The tissue homogenate was centrifuged at $10,000 \mathrm{Xg}$ for $20 \mathrm{~min}$ at $4^{\circ} \mathrm{C}$ and aliquots of supernatant were transferred from the centrifuge tube and used for following biochemical estimations except sodium, potassium ATPase activity estimation

In the case of sodium, potassium ATPase activity estimation the brain was weighed and homogenized $(1: 10 \mathrm{w} / \mathrm{v})$ in sucrose isotonic buffer $(0.32 \mathrm{mM}$ sucrose, $12.5 \mathrm{mM}$ Tris and $1 \mathrm{mM}$ EDTA), $\mathrm{pH} 7.4$ and dilution 1:19. The homogenate was centrifuged at $10,000 \times \mathrm{g}$ for $20 \mathrm{~min}$ at $4^{\circ} \mathrm{C}$ and aliquots of 
supernatant were transferred from the centrifuge tube and used for the estimation of sodium, potassium-ATPase activity.

\section{Assay for Lipid Peroxidation (LPO)}

The lipid peroxidation product in brain homogenate was measured through the estimation of thiobarbituric acid reactive substances (TBARS) levels by the method as described by Buege and Aust (3).

Assay procedure: One milliliter of sample was precipitated with $2.5 \mathrm{ml}$ of ice cold TCA and mixed thoroughly. Samples were kept for centrifugation at $3000 \mathrm{~g}$ for ten minutes. To $2 \mathrm{ml}$ of this supernatant, $2 \mathrm{ml}$ of $0.67 \%$ of thiobarbituric acid (TBA) was added and mixed thoroughly, kept in boiling water bath for ten minutes and cooled under the tap water. The absorbance of pink chromogen determined at $532 \mathrm{~nm}$ against the water blank using a Systronic-117 UV-Visible spectrophotometer. TBARS concentration ( $\mu$ moles/g of tissue) was calculated using molar extinction coefficient of chromophore $(1.56 \mathrm{x}$ $\left.10^{5}(\mathrm{~mol} / \mathrm{l})^{-1} \mathrm{~cm}^{-1}\right)$.

\section{Estimation of Advanced Oxidative Products of Protein (AOPPs)}

Advanced oxidative products of protein were assessed according to the method depicted by Witko-Sarsat (23).

Assay procedure: Brain supernatant was diluted with normal saline (1:10). To that, $200 \mu \mathrm{l}$ of $1.16 \mathrm{M} \mathrm{KI}$ was added and kept for 2 minute. Later $400 \mu \mathrm{l}$ of acetic acid was added. Similarly a sample blank was prepared containing only normal saline and other reagents as above. The absorbance was measured spectrophotometrically with a Systronic-117 UV-Visible spectrophotometer at $340 \mathrm{~nm}$. Concentration of AOPP was calculated by using the extinction coefficient of $26 \mathrm{mM}^{-1} \mathrm{xcm}^{-1}$ and the values were expressed in $\mu$ moles/lit.

\section{Assay of Reduced Glutathione (GSH)}

Tissue GSH concentration was assessed according to the method depicted by Ellman $(7,20)$

Assay procedure: One milliliter of sample was precipitated with $1 \mathrm{ml}$ of glacial metaphosphoric acid and cold processed at four degree Celsius for 1 hour. The samples were kept for centrifugation at $1,200 \mathrm{~g}$ at four degree Celsius for $15 \mathrm{~min}$. One $\mathrm{ml}$ of supernatant separated. $2.7 \mathrm{ml}$ of phosphate buffer and $0.2 \mathrm{ml}$ of 5, 5' dithio-bis-2-nitrobenzoic acid (DTNB) were added. The absorbance of yellow colour was determined at $412 \mathrm{~nm}$ against the water blank using a Systronic-117 UVVisible spectrophotometer.

\section{Assay of $\mathrm{Na}^{+}, \mathrm{K}^{+}$-ATPase Activity}

$\mathrm{Na}^{+}, \mathrm{K}^{+}$-ATPase activity was determined by the method of Wyse (24).

Assay procedure: $0.1 \mathrm{ml}$ of samples and ATP solution are thawed and kept in ice bath. $0.25 \mathrm{ml}$ of reaction mixture (1M $\mathrm{Nacl}, 0.1 \mathrm{M} \mathrm{Mgcl} \mathrm{2}^{\prime} 0.5 \mathrm{M}$ of Tris $\mathrm{HCL}$ ) was taken two test tubes. $10 \mathrm{mM}$ of oubain added to one test tube and equal volume of double distilled to another test tube. Enzyme preparation was added to both test tubes. Reaction is initiated with addition of 50 microliter of ATP solution. The reaction was stopped by adding $0.5 \mathrm{ml}$ of $10 \%$ TCA and both test tubes were immediately transferred to ice bath for $10 \mathrm{~min}$. the tubes were centrifuge at $1000 \mathrm{Xg}$ to remove the precipitate. Whole supernatant was taken for phosphate estimation by FiskeSubbarow. Enzyme specific activity was expressed as $\mu \mathrm{mol} \mathrm{Pi}$ released $/ \mathrm{mg}$ of protein $/ \mathrm{hr}$.

\section{RESULTS}

\section{Lipid peroxidation in brain}

The level of the thiobarbituric acid reactive substances (TBARS) is a marker of lipid peroxidation. Animals exposed to stress (21 days) showed a significant increase in TBARS level in the brain compared to control (group-1 vs. group-2, $p<0.001$ ). Animals exposed to stress along with Acorus calamus (group-3 and group-4) showed a significant decrease in TBARS level in the brain compared to stressed animals (group- 2 vs. group-3 \& group-4, $p<0.001)$. No significant change in the level of TBARS was observed in the brain of animals exposed to stress along with $A C$ at the dose of 100 and $200 \mathrm{mg} / \mathrm{kg}$ body weight (group-3 \& group-4) (Figure 1).

\section{Reduced glutathione (GSH) level in brain}

Animals received restrained stress for 21 days (group-2) showed no significant changes of GSH level in the brain compared to control (group-1 vs. group-2, $p>0.5$ ). Animals who received restrained stress along with $A C$ treatment (group-3 \& group-4) showed a significant increase $(p<0.01$, $p<0.05)$ in GSH level when compared to restrained stressed animals (group-2). No significant change in GSH level was observed in animals exposed to restrained stress along with AC at the dose of 100 and $200 \mathrm{mg} / \mathrm{kg}$ body weight (group-3 \& group-4) (Figure 2).

\section{Advanced oxidative products of protein (AOPPs) level in the brain}

The AOPPs level significantly increased in the brain of restrained stressed animals (group-2) compared to control (group-1 vs. group-2, $p<0.001$ ). However, animals exposed to restrained stress along with AC (group-3, group-4) failed to decrease $(p>0.05)$ the AOPPs level in the rat brain (Figure 3$)$.

\section{4. $\mathrm{Na}^{+}, \mathrm{K}^{+}$-ATPase activity in brain}

$\mathrm{Na}^{+}, \mathrm{K}^{+}$-ATPase activity in brain homogenate was found to be linear $\left(R^{2}\right.$ linear $\left.=0.87\right)$. The Linearity of the reaction was assessed by quantifying the inorganic phosphate concentration liberated at 15, 30, 45, 60, 75, $90 \mathrm{~min}$ respectively, while maintaining the concentrations of other ions $\left(\mathrm{Na}^{+}, \mathrm{K}^{+}, \mathrm{Mg}^{2+}\right)$, ATP constant. $\mathrm{Na}^{+}, \mathrm{K}^{+}$-ATPase activity was significantly decreased $(p<0.05)$ only in the animals who received restrained stress for 21 days (group-2) compared to control (group-1). Post stress induction, treatment with AC (both $100 \& 200$ ) enhanced the $\mathrm{Na}^{+}, \mathrm{K}^{+}$-ATPase (group-2 vs. group-3, group-4, $p<0.05, p<0.001)$ activity. Among the two doses, AC $200 \mathrm{mg} / \mathrm{kg}$ showed better response compared to $100 \mathrm{mg} / \mathrm{kg}$. (group-3 vs. group-4, $p<0.05$ ) (Figure 4). 


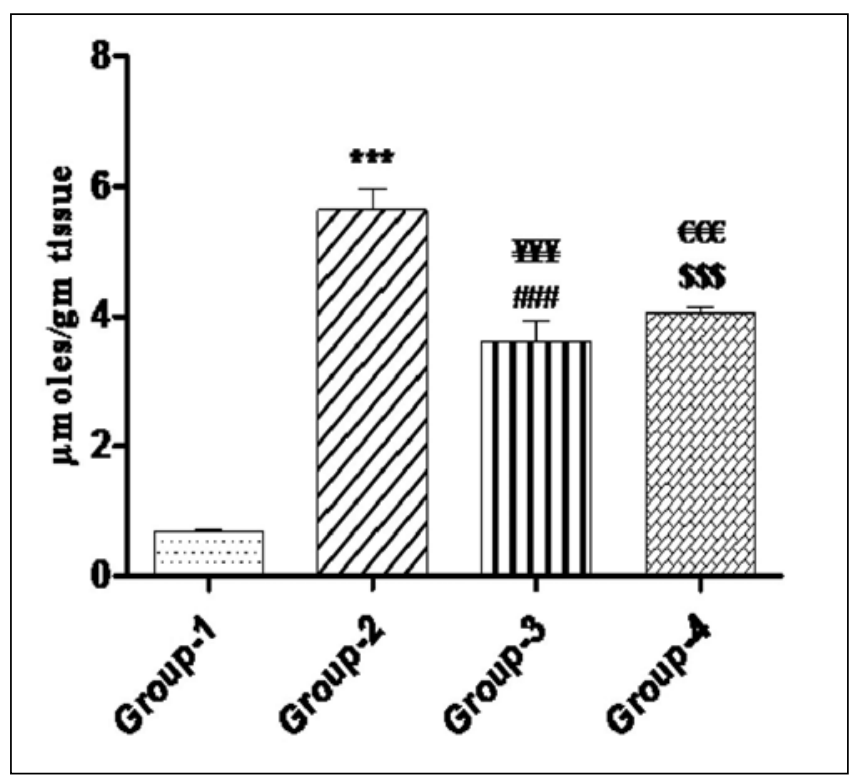

Figure 1: Effects of restrained stress and Acorus calamus administration on the TBARS ( $\mu$ moles/gm of tissue) level in the brain. ANOVA significance (Bonferroni's test, each bar represents mean \pm SEM, $\mathrm{n}=06$ per group).

$P<0.0001 \& \mathrm{~F}=72.832$

group-1 vs. group-2, group-3 \& group- $4,{ }^{* * *} p<0.001,{ }^{* \# \#} p<0.001$, $\epsilon \epsilon \epsilon_{p}<0.001$, group-2 vs. group-3 \& group- $4,{ }^{¥ *} p<0.001,{ }^{\$ \$ \$} p<0.001$

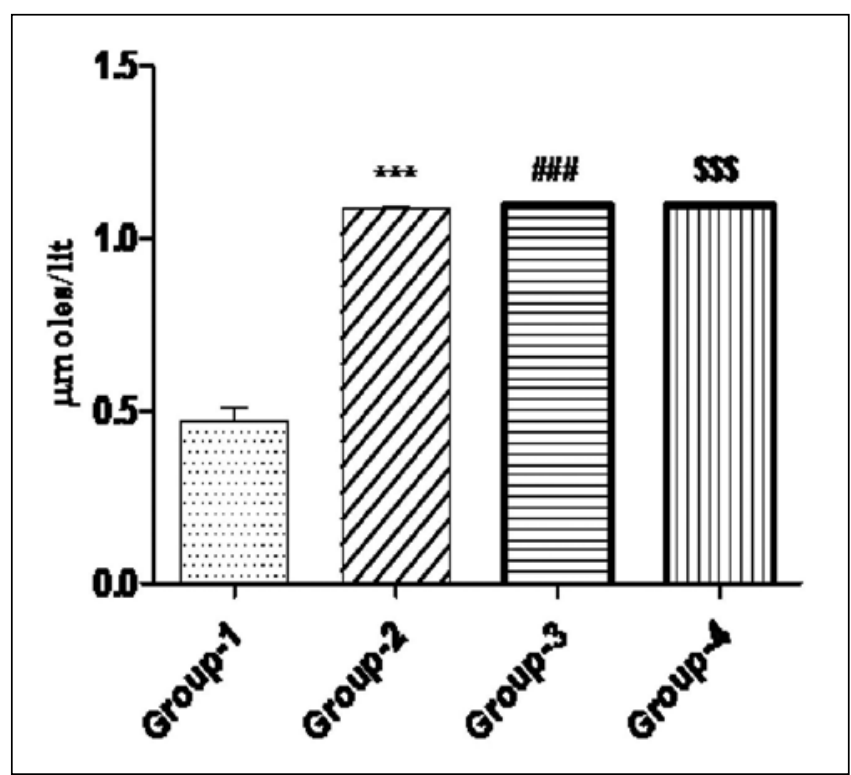

Figure 3: Effects of restrained stress and AC administration on advanced oxidative products of protein ( $\mu$ moles/lit) level in the brain. ANOVA significance (Bonferroni's test, each bar represents mean \pm SEM, $\mathrm{n}=06$ ).

$P<0.0001 \& \mathrm{~F}=262.015$

group-1 vs. group-2, group-3 \& group- $4,{ }^{* * *} p<0.001,{ }^{\# \# \#} p<0.001$, $\$ \$ \$ p<001$

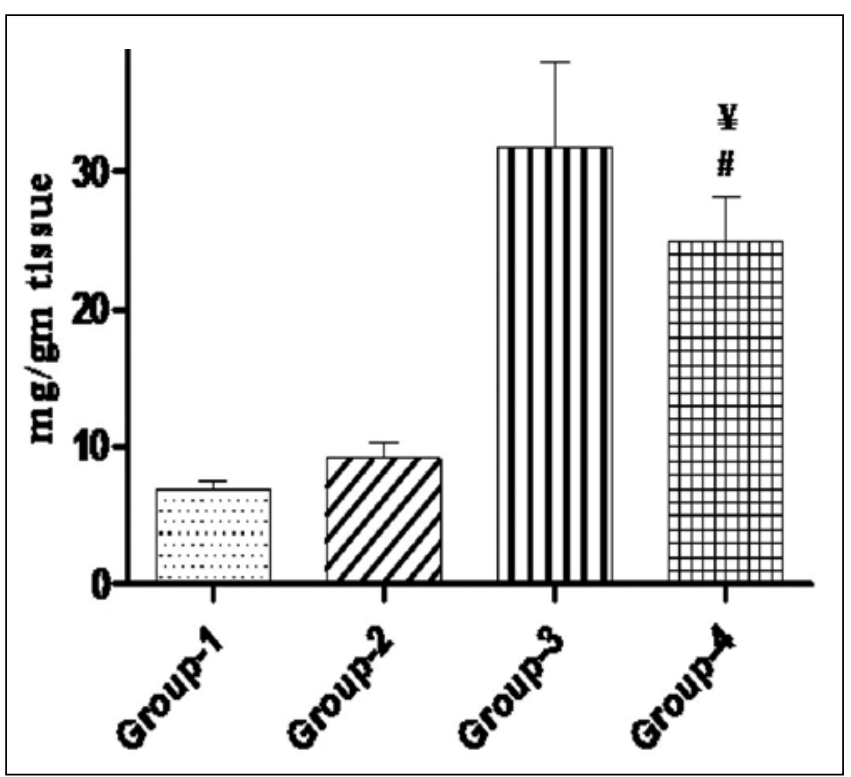

Figure 2: Brain reduced Glutathione level ( $\mathrm{mg} / \mathrm{gm}$ of tissue) in rats. ANOVA significance (Bonferroni's test, each bar represents mean \pm SEM, $\mathrm{n}=06$ ).

$P<0.0001 \& F=11.465$

group-1 vs. group-3 \& group- $4,{ }^{* * *} p<0.001,{ }^{*} p<0.05$

group-2 vs. group-3 \& group-4, ${ }^{\$ \$ \$} p<0.001,{ }^{¥} p<0.05$

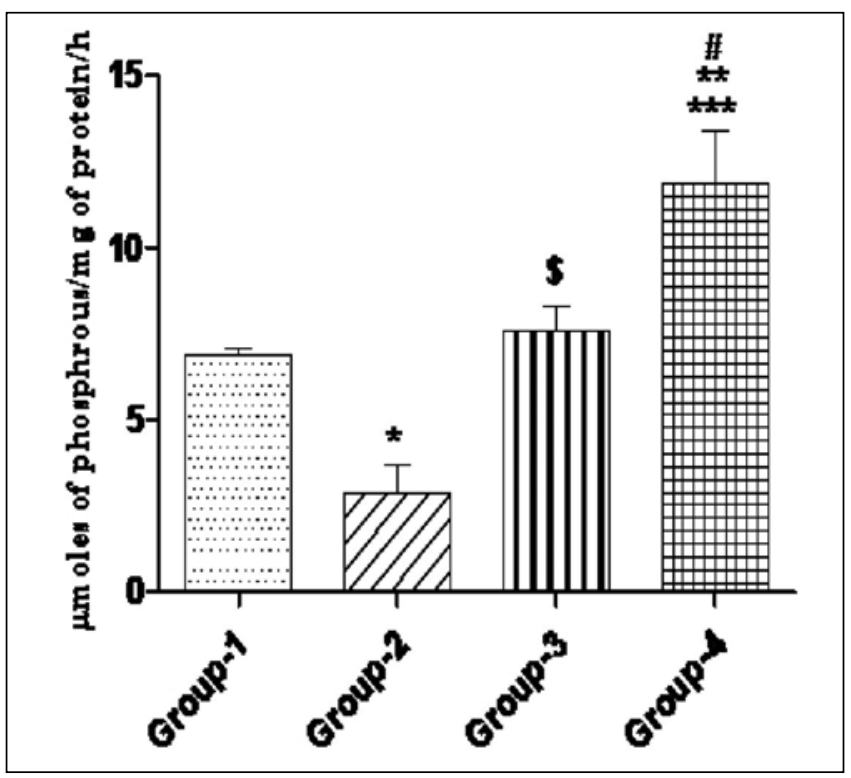

Figure 4: Brain $\mathrm{Na}^{+}, \mathrm{K}^{+}$-ATPase activity ( $\mu \mathrm{mol}$ of phosphorus/mg of protein/h) in rats. ANOVA significance (Bonferroni's test, each bar represents mean $\pm S E M, n=06$ per group).

$P<0.001 \& \mathrm{~F}=15.671$

group-1 vs. group-2, group- $4,{ }^{*} p<0.05,{ }^{* *} p<0.01$

group-2 vs. group-3, group-4, ${ }^{5} p<0.05,{ }^{* * *} p<0.001$

group-3 vs. group- $4,{ }^{*} p<0.05$ 


\section{Elevated plus maze}

Stressed rats (group-2) showed a marked decrease in the number of open arm entries $(p<0.05)$, total arm entries $(p<0.001)$, time spent in open arm $(p<0.05)$, and also an increase in the time spent in closed arms $(p<0.05)$ compared to controls, indicating anxiety-like behavior. Treatment with AC (100 and $200 \mathrm{mg} / \mathrm{kg} /$ day) significantly increased the number of open arm entries and total arm entries compared to stressed rats (group-2). This suggests an anxiolytic activity

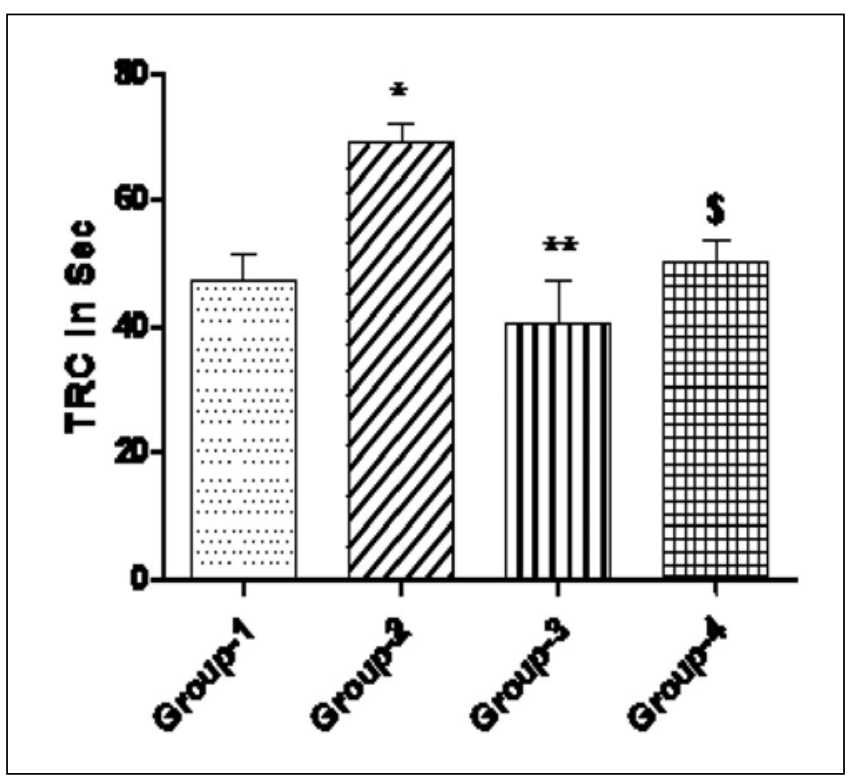

Figure 5: Effect of chronic restraint stress and $A C$ treatment on time to reach reward chamber (TRC) of rats using Hebb-Williams Maze. Data are expressed as mean \pm SEM ( $n=6$ per group).

group-1: control, group-2: rats received restraint stress (6h/day) for 21 days, group-3: rats received both restraint stress and AC (100 mg/kg/day) for 21 days and group-4: rats received both restraint stress and AC ( $200 \mathrm{mg} / \mathrm{kg} /$ day) for 21 days.

Control (group-1) vs. Group-2: ${ }^{*} p<0.05$

group-2 vs. Group-3, group-4: ${ }^{* *} p<0.001,{ }^{*} p<0.05$. (One-way ANOVA with Bonferroni's corrections). of $A C$. The effect of restraint stress and AC treatment on the number of rearings was not statistically significant $(p=0.173$, $F=1.664$ ) (Table I).

\section{Hebb-Williams Maze}

The rats that were under stress took a significantly longer time to reach the reward chamber (TRC) from the start box compared to controls $(p<0.05)$. This clearly indicates that chronic stress impairs learning and memory abilities. Post treatment with AC treatment (group-3 and group-4) showed a significant $(p<0.01, p<0.05)$ decrease in TRC compared to stressed rats (group-2). This result demonstrates that $A C$ treatment not only minimizes the stress effects, but also enhances the learning and memory abilities in rats (Figure 5).

\section{DISCUSSION}

The overt effects of prolonged restraint stress on neurological functions such as spatial learning, anxiety and memory are well studied (26). The hippocampus plays a crucial role in modulation of cognitive functions. Chronic stress-induced changes such as retraction of apical dendrites in the CA3 region and changes in the shape as well as dendritic spine number (21) of the rat hippocampus have been reported (12). Long-lasting stressful periods can result in neuronal cell death (21). Together there is enough evidence that exposure to stress over a period of time has a noticeable effect on the hippocampal morphology and anatomy. This can be attributed to the impaired spatial learning and memory in the stress-induced group. In our study, chronic stress increased anxiety-like behaviour was evident by decreased open arm entries and time spent in open arms. Our findings were consistent with earlier reports $(2,9)$.

Adaptation to stress requires several homeostatic adjustments such as release of hormones, neurotransmitters and other mediators. In the short term they all have beneficial effects but in the long term they may culminate and lead to harmful effects. Such imbalances and the over-interaction may cause increased oxidant generation coupled with decreased antioxidant defence in mitochondria leading to oxidative damage to biomolecules in particular (11).

Table I: Role of Anxiety Level in the Effects of Acorus calamus on the Immobility of Rats in Elevated Plus Maze

\begin{tabular}{|l|c|c|c|c|}
\hline Parameters & \multicolumn{4}{c|}{ Treatments } \\
\hline Number of open arm entries & Group-1 & Group-2 & Group-3 & Group-4 \\
\hline Number of total arm entries & $3.33 \pm 0.33$ & $1.5 \pm 0.47^{\mathrm{a}}$ & $3.83 \pm 0.47^{\mathrm{b}}$ & $4.83 \pm 0.547^{\mathrm{c}}$ \\
\hline Percent of entries to open arms & $10.5 \pm 0.50$ & $4.16 \pm 0.47^{\mathrm{c}}$ & $5.16 \pm 0.65$ & $9.33 \pm 0.88^{\mathrm{c}}$ \\
\hline Time spent in open arm(s) & $67.11 \pm 4.21$ & $4.83 \pm 0.872$ & $66.6 \pm 23.45$ & $89.33 \pm 11.41$ \\
\hline Time spent in closed arm(s) & $74.5 \pm 4.603$ & $84.1 \pm 6.812^{\mathrm{a}}$ & $79 \pm 12.198^{\mathrm{a}}$ & $19.3 \pm 4.098^{\mathrm{b}}$ \\
\hline Number of rearing(s) & $89.0 \pm 7.9$ & $280.16 \pm 23.06^{\mathrm{c}}$ & $186.1 \pm 23.06^{\mathrm{a}}$ & $114 \pm 15.49^{\mathrm{c}}$ \\
\hline
\end{tabular}

Data are expressed as mean \pm SEM ( $n=6$ per group). group-1: control, group-2: rats received restraint stress (6h/day) for 21 days, group-3: rats received both restraint stress and AC (100 mg/kg/day) for 21 days and group-4: rats received both restraint stress and AC (200 mg/kg/day) for 21 days. Control (group-1) vs. group-2, group-4: ${ }^{a} p<0.05,{ }^{c} p<0.001$; group-2 vs. group-3, group-4: ${ }^{a} p<0.05,{ }^{b} p<0.01$; group-3 vs. Group-4: ${ }^{c} p<0.001$ (One way ANOVA with Bonferroni's corrections). 
Invariably these defence mechanisms become saturated or incompetent and then tissue damage begins. It is therefore important to support endogenous defence mechanism(s) by supplementing antioxidants from an external source.

Antioxidant agents which are able to inhibit reactive species (ROS) generation, oxidative damage may ameliorate cognitive dysfunction. Plants and plant-derived products are known to possess rich antioxidant principles. Several studies have shown the potent antioxidant and free radical generation inhibitory effects of Acorus calamus $(1,18)$. Thus, this study aimed to investigate the neuroprotective effects of AC against chronic stress-induced memory impairment. Acorus calamus treatment prevented the chronic stress-induced memory impairment and the anxiogenic behavior, indicating its neuroprotective activity. The anti-anxiety activity of AC may be due to reserpine-like action in the rat brain (13). The main constituents of $A C$ include $\alpha$ and $\beta$-asarone. Recent evidence has revealed NMDA (N-methyl-D-aspartate) receptor blockade activity of asarone. This might be responsible for the neuroprotective effect against NMDA or glutamate-induced excitotoxicity (4). It has been reported that excitotoxicity is one of the causative factors of cognitive dysfunction. Hence, this may be one of the neuroprotective mechanisms of $A C$ in the rat paradigm of chronic stress-induced memory impairment.

In conclusion, the results of the present study suggested that chronic stress could lead to cognitive dysfunction and anxiety in rats. We also found that $A C$ treatment effectively prevented stress-induced cognitive dysfunction and anxious behaviour. These effects are likely mediated by its antioxidant activities. Thus our results clearly indicate the neuroprotective effect of $A C$ against restraint stress-induced neuronal damage. Future studies are needed to elucidate the cellular mechanisms with multiple and diverse models of learning and memory. This can create new possibilities in the management of stressrelated disorders.

\section{REFERENCES}

1. Acuna UM, Acuna, UM, Atha DE, Ma J, Nee MN, Kennelly EJ: Antioxidant capacities of ten edible North American plants. Phytother Res 16: 63-65, 2002

2. Alfarez $D$, Joels $M$, Krugers $H$ : Chronic unpredictable stress impairs long-term potentiation in rat hippocampal CA1 area and dentate gyrus in vitro. The European Journal of Neurosciences 17(9): 1928-1934, 2003

3. Buege JA, Aust SD: Microsomal lipid peroxidation methods. Enzymol 52: 302-310, 1978

4. Cho J, Kim YH, Kong JY, Yang CH, Park CG: Protection of cultured rat cortical neurons from excitotoxicity by asarone, a major essential oil component in the rhizomes of Acorus gramineus. Life Sci 71(5): 591-599, 2002

5. Das PK, Malhotra CL, Dhalla NS: Spasmolytic activity of asarone and essential oil of Acorus calamus Linn. Arch Int Pharmacodyn 135: 167-177, 1962
6. Dhalla NS, Bhattacharya IC: Further studies on neuropharmacological actions of Acorus oil. Arch Int pharmacodyn 172: 356-365, 1968

7. Ellman GL: Tissue sulfhydryl groups. Arch Biochem Biophys 82: 70-77, 1959

8. Hebb DO, Williams K: A method of rating animal intelligence. J Gen Psychol 34:59-65,1946

9. Joels $M$, Karst $H$, Alfarez $D$, Heine $Y$, Van Riel $Y$, Verkuyl $M$, Lucassen $\mathrm{P}$, Krugers $\mathrm{H}$ : Effects of chronic restraint stress on structure and cell function in rat hippocampus and hypothalamus. Stress 7(4): 221-231, 2004

10. Koo BS, Park KS, Ha JH, Park JH, Lim JC Lee DU: Inhibitory effects of the fragrance inhalation of essential oil from Acorus gramineus on central nervous system. Bio Pharm Bull 26: 978-982, 2003

11. Liu J, Mori A: Stress, aging, and brain oxidative damage. Neurochem Res 24: 1479-1497, 1994

12. Magariños AM, McEwen BS: Stress-induced atrophy of apical dendrites of hippocampal $\mathrm{CA}_{3}$ neurons: Comparison of stressors. Neurosci 69: 83-88,1995

13. Malhotra CL: Effect of hersaponin and acorus oil nor adrenaline and 5-hydroxy triptamine content of rat brain. J Pharm Pharmacol 13: 447-456, 1961

14. Mukherjee PK, Kumar V, Mal M, Houghton PJ: In vitro cetylcholinesterase inhibitory activity of the essential oil from Acorus calamus and its main constituents. Planta Medica 73:83-285, 2007

15. Panchal GM, Venkatakrishna, Bhatt H, Doctor RB, Vajpayee S: Pharmacology of Acorus calmus Linn. Indian J Exp Biol 27(6): 561-567, 1989

16. Pellow S, Chopin P, File SE, Briley M: Validation of open-closed arm entries in elevated plus maze as a measure of anxiety in rat. J Neurosci Methods 14: 149-167,1985

17. Shah LP, Patil SP, Patil J: Observations on clinical evaluation of indigenous herbal drugs in the treatment of mental illnesses. Indian J Pharmacol 29:347-350, 1997

18. Shahin SA, Naresh K, Abhinav L, Angad S, Hallihosur S, Abhishek S, Utpal B: Review Indian medicinal herbs as sources of antioxidants. Food Research International 41: 1-15, 2008

19. Shukla PK, Khanna V, Ali M, Maurya R, Khan MY, Srimal RC: Neuroprotective effect of Acorus calamus against middle cerebral artery occlusion-induced ischaemia in rat. Human and Experimental Toxicology 5: 187-194, 2006

20. Sudhanshu S, Sampath M, Gayathri R: Effect of Prenatal stress on expression of glutathione system in neonatal rat brain. Turk Neurosurg 22(5):576-582, 2012

21. Sunanda Rao MS, Raju TR: Effect of chronic restraint stress on dendritic spines and excrescences of hippocampal $\mathrm{CA}_{3}$ pyramidal neurons- a quantitative study. Brain Res 694: 312-317, 1995

22. Vale WW, Spiess J, Rivier C, Rivier J: Characterization of a 41-residue ovine hypothalamic peptide that differential environmental modulations on locomotor activity, exploration and spatial behaviour in young and old rats. Physiol Behav 59:265-271, 1981 
23. Witko-Sarsat VM, Friedlander C, Capeillere-Blandin T, et al: Advanced oxidation protein products as a novel marker of oxidative stress in uremia. Kidney Int 49: 1304-1313, 1996

24. de Souza Wyse AT1, Streck EL, Worm P, Wajner A, Ritter $F$, Netto CA: Preconditioning prevents the inhibition of $\mathrm{Na}+, \mathrm{K}+-$ ATPase activity after brain ischemia. Neurochem Res 25(7):971-975, 2000
25. Youdim KA, Joseph JA: A possible emerging role of phytochemicals in improving age-related neurological dysfunctions: A multiplicity of effects. Free Rad Biol Med 30:583-594: 2001

26. Zhihui Feng, Haiqun Jia, Xuesen Li, Zhuanli Bai, Zhongbo Liu, Lijuan Sun, et al: A milk-based wolfberry preparation prevents prenatal stress-induced cognitive impairment of offspring rats, and inhibits oxidative damage and mitochondrial dysfunction in vitro. Neurochem Res 35: 702-711: 2010 